\title{
Research of Shanghai Cruise Industry Chain Distribution of Benefits
}

\author{
Ling Sun ${ }^{1}, \mathrm{Li} \mathrm{Tang}^{2}$, Xiao-di Bao ${ }^{3}$ and Wei Liu ${ }^{4}$ \\ College of Transport \& Communications, Shanghai Maritime University, \\ No.1550 Haigang Av. Lingang New City, pudong District, Shanghai, PR China. \\ ${ }^{1}$ sonnezyzzyva@aliyun.com, ${ }^{2}$ jixitl@163.com, ${ }^{3}$ returnboy@sina.com, \\ 4weiliu@shmtu.edu.cn
}

\begin{abstract}
Based on the Shanghai cruise industry research, this cruise industry chain has problems with balance. Game theory was used and imbalance mainly due to lack of shipbuilding enterprises and proprietary cruises, and also because foretg cruise companies dominate Shanghai cruise industry chain. Learning from the successful experience of foreign cruise homeports' development, the paper consider transferring the chain's dominant right to the port enterprise gradudlly. Using Shapley Model to solve benefits distribution of cruise industry chain dominated by port companies. The profits distribution ratio of cruise companies, port companies and service supporting enterprises is $\frac{13}{48}: \frac{47}{96}: \frac{23}{96}$. Nash Model was also used to stud the benefits distribution of industry chain whose member companies are equal. Modeling results show that Shapley Model corresponds with the requirements of benefit maximizafion. Finally, a validation analysis was done and proved that only the cruise industry chain leaded by homeport that can maximize the economic benefits.
\end{abstract}

Keywords: Cruise; Industry chain; Thedistribution of benefits

\section{Introduction}

Cruise tourism is the most potential industry in the tourist industry, and with the developmen of cruise industry, researches on the cruise industry are increased at home and abroad. Based on the practice experience on a Florida international cruse company, Simon Véronneau and Jacques Roy [1]do research on each link and all factors of cruise supply chain management and at last give various resources complex system's supply chain management model. Mamoozadeh and G.Abbas [2] reveal the significance of the destination ports economic development and influence of its income growth both affected by cruise tourism. In Larry Dwyer and Peter Forsyth's research [3], the economic significance of cruise industry is analyzed. Iwata $\mathrm{H}$. Matsudak [4]points out that cruise tourim s the fast growing industry in the tourist industry according to his analysis on supply and demand of the global cruise market.

According to Development Research Center of the State Council(2003) [5], cruise industry which will be a regional economic growth pole can drive development of upstream and downstream related industries, and thus forming an economic association composed by multiple industries.Yu Sijia(2005)[6] thinks cruise supply chain is capable to bring cruise homeport huge economic benefits. Through the cost estimate analysis of building large and medium-sized cruise port, Mai Youhong, Jin Wenzheng and Ji Yongbo(2008)[7] put forward measures to control the risk of investment. In Yang Ming and Chen Juans' opinion (2009)[8], problems of Chinese cruise tourism market are the insufficient of both tourist cognition and power of consumption in demand, and poor performance in infrastructure, tourism product and supporting service. Xu Lian(2011)[9] 
believes that Chinese cruise industry chain hasn't involve upstream link at present. It's necessary to develop shipbuilding industry and establish local cruise lines for China to optimize its cruise industry chain.

There is little research of Shanghai cruise industry chain benefits distribution as yet in China though many studies on cruise industry from different perspectives are made by academics, universities and related departments. In Chinese Academic Journal Index, fuzzy search and precise search methods are used and key words are cruise tourism, cruise economic, cruise industry, cruise port, and so on. The Figure 1, illustrates the search result.

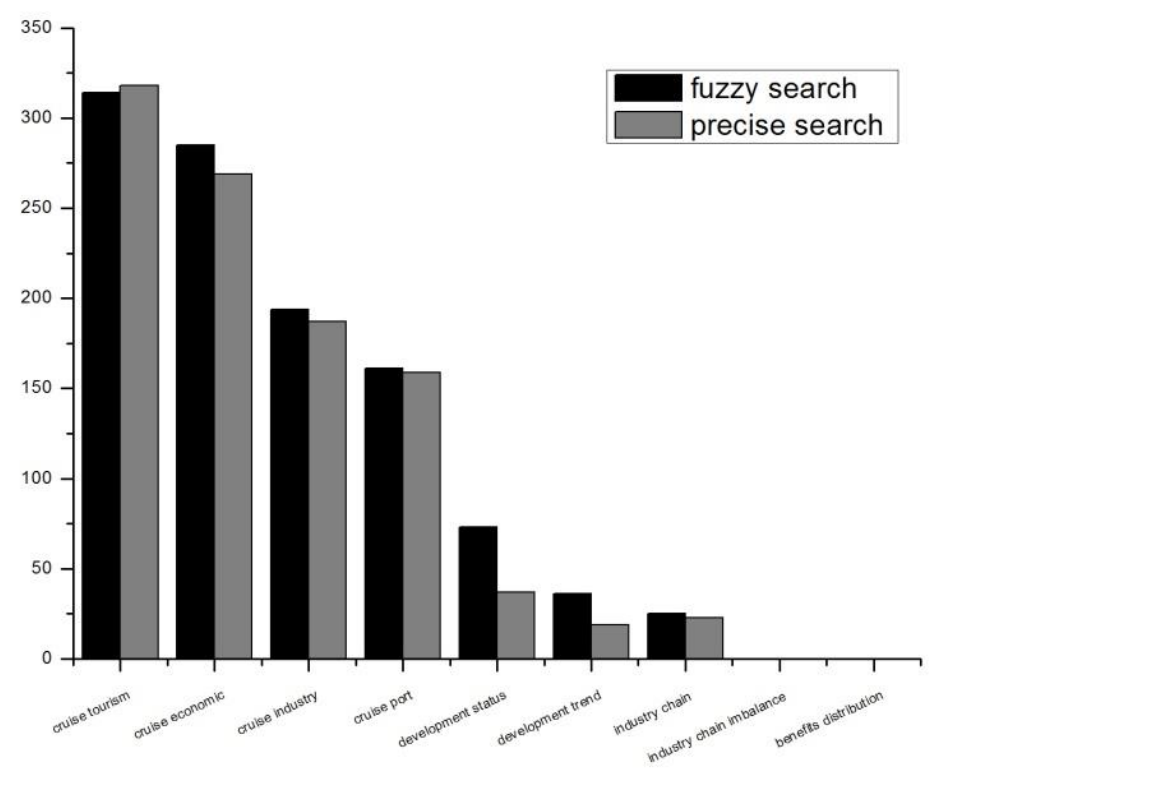

Figure 1. Crulise Research Situation

After making clear of theory knoyledge about industry chain, we interviewed cruise sports, research centers, cruise lines and other related departments in order to learn the situation of crurse industry chain benefits distribution. The research shows that though the number of internationat cruise ships docked in Shanghai Port and passengers is increasing, the port operation is not good. Since that, researching Shanghai cruise industry chain benefits distribution has some referential significance of perfecting the theory system of the craise industry chain and increasing home ports' economic benefits.

\section{Overview of Shanghai Cruise Industry}

\section{Current Situations of Shanghai Cruise Industry}

Shanghai international passenger center locates in downtown which is a superior geographic location. It is available for three 70 thousand-class luxury cruise ships at the same time, providing piloting all the day, and its annual designed customs clearance capacity is one million persons. The total investment of Wusong international cruise port was 1.26 billion yuan, and the area is over 1.6 billion square meters, which can allows 10 to 15 tons of three large cruise ship. Its designed annual clearance capacity is 680 thousand persons.

The number of international cruise ship arrive at Shanghai has been increased every year since 2002 and in 2014 the number is up to 269, which is 24 times higher than 
2003's. Besides, the number of cruise tourists in 2014 is 1215.2 thousand and is 74 times higher than in 2003.

\subsection{Shanghai Cruise Industry Chain Economic Contribution Analysis}

According to the 12th five-year of Shanghai cruise tourism plan, at the end of this period of time, the number of cruise ship based on Shanghai home port will be 5 to 8 , and the cruise tourists number will be more than million persons while the direct economic benefits to Shanghai port by cruise industry is expected to reach 50 to 80 yuan billion. In this paper, covariance model is approved according to the cruise tourists' quantity from 2002 to 2011. Based on the model, the cruise tourists' number, GDP of Shanghai, the tertiary industry's GDP of Shanghai, output value of Shanghai tourism and foreign currency earnings from international tourists, the correlation of each two of them are calculated.

Table 1.Correlation Coefficients of each Sample

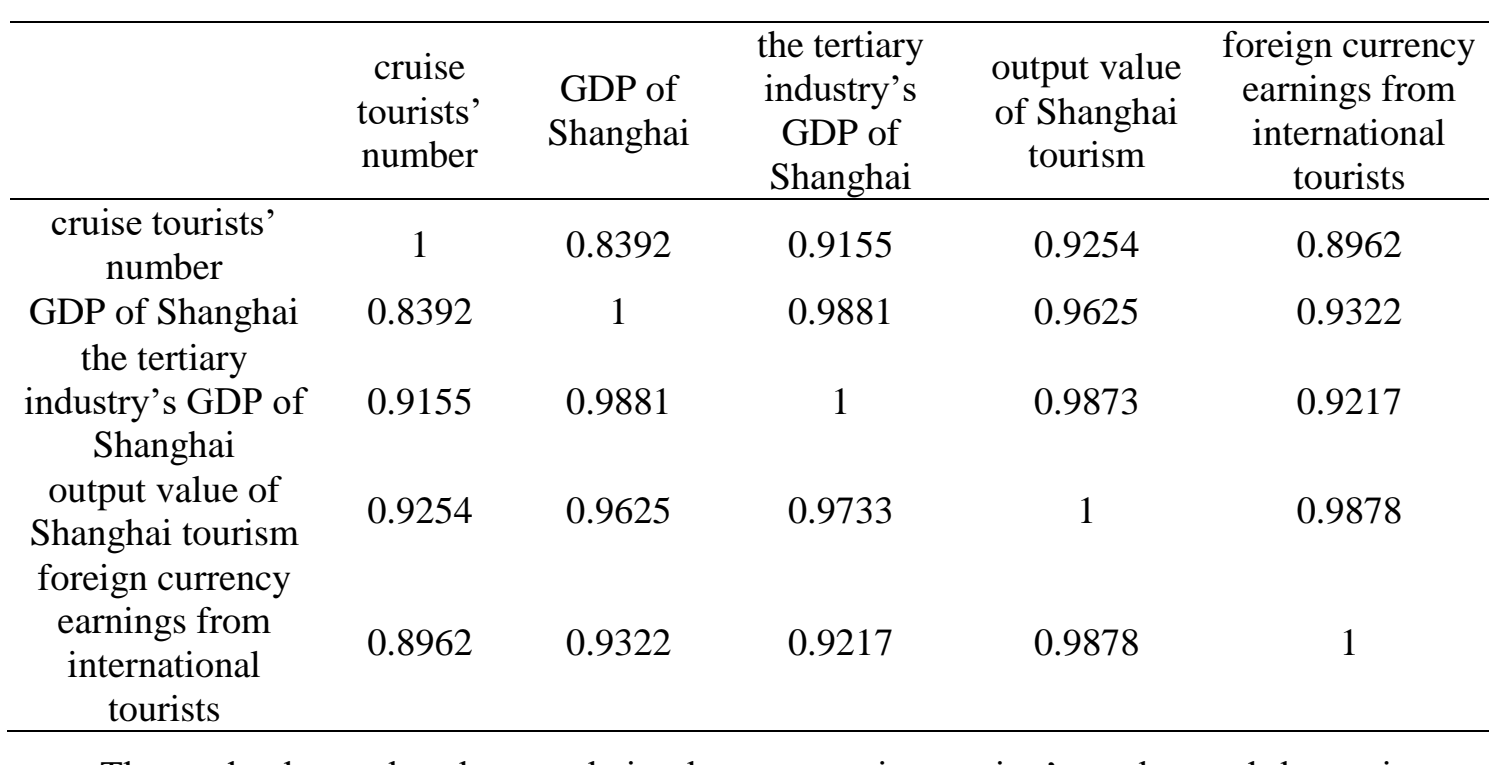

The study shows that the correlation between cruise tourists' number and the tertiary industry's GDP of Shang is over $90 \%$ and the correlation between cruise tourists' number and output value of Shanghai tourism is the same. Moreover, the correlation between GDP of Shanghar and the tertiary industry's GDP is over 96\%, just as GDP of Shanghai and output value of Shanghai tourism's.

\section{Analysis of Shanghai Cruise Industry Chain}

\subsection{Contrast of the Cruise Industry Economic Structure between Foreign Country and Shanghai}

IA's research shows that core projects, manufacturing and government service are the most important parts of cruise industry's direct economic earnings. According to the proportion of core projects from large to small are port service, travel agency, and airline service and tourist consumer. In china, however, cruise industry's direct earnings are mainly from port service and tourists reception which are with low additional value. Due to the lack of cruise ship manufacturing and government service, we can only analyze core projects' economic structure. 

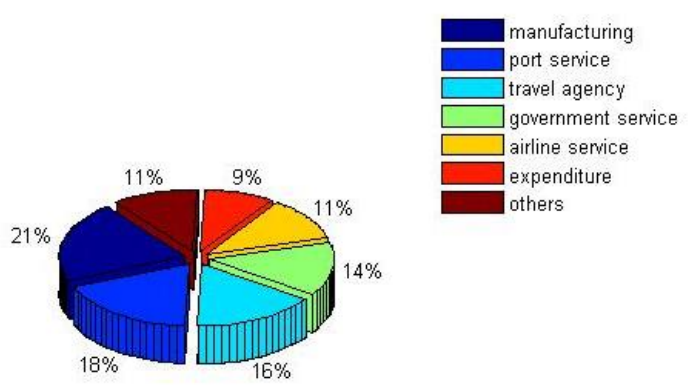

Figure 2. Foreign Cruise Industry Income Distribution

\section{Table 2. Domestic and Foreign Cruise Industry's Core Projects Economic Structure Contrast}

\begin{tabular}{|c|c|c|}
\hline project & Foreign core projects & Domestic core projects (Shanghai) \\
\hline $\begin{array}{c}\text { Port } \\
\text { service }\end{array}$ & $\begin{array}{l}\text { Harbor dues, ship supply, ticket } \\
\text { agent, crew labor output, ship repair } \\
\text { and duty-free shop account for } 18 \% \\
\text { of cruise industry direct income and } \\
33 \% \text { of core projects. }\end{array}$ & $\begin{array}{l}\text { Only in charge of two cruise ships' } \\
\text { ship supply consumption in duty-free } \\
\text { shop per person is about } 50 \text { to } 60 \\
\text { RMB, harbor dues is } \$ 23 \text { per person } \\
\text { per time, design profit accounts for } \\
3 \%\end{array}$ \\
\hline $\begin{array}{c}\text { Tourist } \\
\text { consumer }\end{array}$ & $\begin{array}{l}\text { Accounting for } 17 \% \text { of core } \\
\text { and consumption per } \\
\$ 1341 \text {. }\end{array}$ & $\begin{array}{l}\text { consumption per person is } \$ 713 \text {, } \\
\text { cruise ship doesn't stay overnight so } \\
\text { the accommodation consumption is } \\
\text { almost zero. }\end{array}$ \\
\hline Airline & $\begin{array}{l}\text { Accounting for } 11 \% \text { of chise } \\
\text { industry direct income and } 21 \% \text { of } \\
\text { core projects }\end{array}$ & $\begin{array}{l}\text { Because the number of mainland } \\
\text { Chinese tourists only accounts for } \\
20 \% \text {, the airline service has no income } \\
\text { from cruise industry. }\end{array}$ \\
\hline Insurance & $\begin{array}{l}\text { Including commercial insurance and } \\
\text { personal insurance. Commercial } \\
\text { insurance is mainlyabout position } \\
\text { insurance and personal insurance is } \\
\text { mainly about pax insurance. }\end{array}$ & $\begin{array}{l}\text { Overseas travel insurance fee is } 68 \\
\text { RMB } 7 \text { days in Ping An Insurance } \\
\text { Company of China, Ltd. The cruise } \\
\text { insurance is insured abroad. }\end{array}$ \\
\hline $\begin{array}{l}\text { Travel } \\
\text { agency }\end{array}$ & $\begin{array}{l}\text { Accounting lor } 16 \% \text { of cruise } \\
\text { industry direct income and } 29 \% \text { of } \\
\text { core projects. }\end{array}$ & $\begin{array}{l}\text { The leader fee is } 20 \mathrm{RMB} \text { per person, } \\
\text { and ticket prices are different in } \\
\text { different travel agency. }\end{array}$ \\
\hline
\end{tabular}

\subsection{Shanghai Cruise Industry Chain's Development Issues Analysis}

3.2.1 No Upstream Link in Shanghai Industry Chain: Upstream industries include cruise design, shipbuilding and maintenance. Luxury cruise manufacturing is a kind of high value-added industries, which can provide more high-end experience, safer, more environmentally friendly than other ships. What is a pity is luxury cruise is so different from general ships that its design and manufacture have little possible to be the core of Chinese shipbuilding industry for a long time in the future.

3.2.2. Industry Chain's Core Link is Immature: The midstream of the chain includes cruise lines and ports. Shanghai has two cruise ports which are homeports for only seven cruise ships. Five ships call at Wusong port while the other calls at North Bund port and both of their operators are foreign cruise lines. Compared with Shanghai port, there are 15 international cruise lines select Miami port as the port of call and the port attracts about 
four million cruise tourists per year. Because of no local cruise lines in China and few foreign cruise lines select Shanghai port as homeport, lines of cruise more limited innovation and product development. Shanghai port wastes lots of resources and its functions cannot be used.

\subsubsection{Defective Function in Industry Chain's Downstream Link}

Ship supply, ashore tourism, commercial trade, recreation, leisure, insurance, transportation and other related service industries constitute the downstream link. At present, Shanghai does not do well in tourism resources planning, homeport consumption environment and international operation. The mechanism of relevant departments linkage is unclear that can't promote the development of cruise. For example, homeport's duty-free goods are in high price but have fewer kinds, ships in port time is short, customs declaration and inspection are limited, the decision power of the food supply which contributes to a quarter of the voyage cost belongs to cruise lines though the port owns the cruise supply system that can do purchase, regulate, distribute and settle accounts Cruise Supply of Shanghai region is still weak in the early stages, and only fresh waterand other basic supplies can be added at this stage. Now, Shanghai port only provide two cruise ships that belong to Costa food and Caribbean's cruise supply provider is in Singapore. It's mainly because the food safety issues and cruise sapply cannot enjoy a 17\% export tax rebates in China.

At this stage, relatively fixed Shanghai cruise ground operators will inevitably bring ashore Tourism products are too single of the drawbacks.

Table 3. Shanghai Cruise Line Shore Journey

\begin{tabular}{|c|c|c|}
\hline $\begin{array}{c}\text { Line } \\
\text { Properties }\end{array}$ & & $\begin{array}{c}\begin{array}{c}\text { Duration } \\
\text { (hours) }\end{array} \\
\end{array}$ \\
\hline & Shanghai Museum - Yu Garden Shanghai Old Street & 4 \\
\hline & Bund - Yu Garden - Shanghai Arts and Crafts Museum & 4 \\
\hline Classic & Jin Mao Tower - Bund - Nanjing Road & 5 \\
\hline Shanghai & Jades Buddha Temple Shanghai Arts and Crafts Museum & 4 \\
\hline $\mathrm{J}^{2}$ & $\begin{array}{l}\text { Bund - Yu Garden - Shanghai Art Institute of Technology - } \\
\text { People's Square - Urban Planning Exhibition Hall - Pudong } \\
\text { New Area - Jin Mao Tower - Riverside Avenue }\end{array}$ & 9 \\
\hline & $\begin{array}{l}\text { Longyang Road Maglev Station - Pudong Airport - Longyang } \\
\text { Road Maglev Station - Lujiazui - Jin Mao Tower }\end{array}$ & 3 \\
\hline eatures & Ohen Moishe Synagogue - French Concession Christian & \\
\hline & $\begin{array}{l}\text { Church - Shanghai Arts and Crafts Institute - High Rd and } \\
\text { Zhoushan Road (the old Jewish settlements) }\end{array}$ & 3.5 \\
\hline & Shanghai Circus Night & 3.5 \\
\hline & Zhujiajiao & 5.5 \\
\hline & Nets Garden in Suzhou - Suzhou No.1 Silk factory system & 9 \\
\hline Shanghai & $\begin{array}{l}\text { Suzhou Humble Administrator's Garden - Canal Cruises - } \\
\text { Chuk Yuen - Lingering Garden - Suzhou Embroidery Museum }\end{array}$ & 10 \\
\hline
\end{tabular}

Today Shanghai Cruise tourist route in accordance with the theme and nature of the cruise line can be divided into three categories like classic Shanghai journey, Features Shanghai journey and journey around Shanghai. In Table 3, the line set out basic tour including most points, we can see Shanghai currently available to cruise ship tourists ashore limited relatively simple products. On the one hand the city tour line is also focused on the side of the tourist attractions Yuyuan, not fully tap the Jinmao Tower, the Oriental Pearl Tower and other traditional attractions; on the other hand, journey around Shanghai are confined to Zhujiajiao and Suzhou tourism. 
Compared with the cruise homeport development abroad, Shanghai cruise industry chain is an imbalance industry chain. Only the industry chain's power of control be switched to port enterprises can prove local economic benefits. Since that, we will analyze the benefits distribution of cruise industry chains dominated by different enterprises.

\section{Analysis of Cruise Industry Chain Benefits Distribution}

Cruise industry chain benefits distribution mechanism is formed because of the wish of durability and stability of industry chain. Because each enterprise's purpose is gaining more profits, it's necessary to build a reasonable mechanism to help maximizing cruise industry chain's overall interests.

\subsection{The Body of the Cruise Industry Chain Benefits Distribution}

The body of the cruise industry chain benefits distribution is the enterprise who distributes the benefits, we call it leading enterprise.

\subsubsection{Industry Chain Dominated by Cruise Lines}

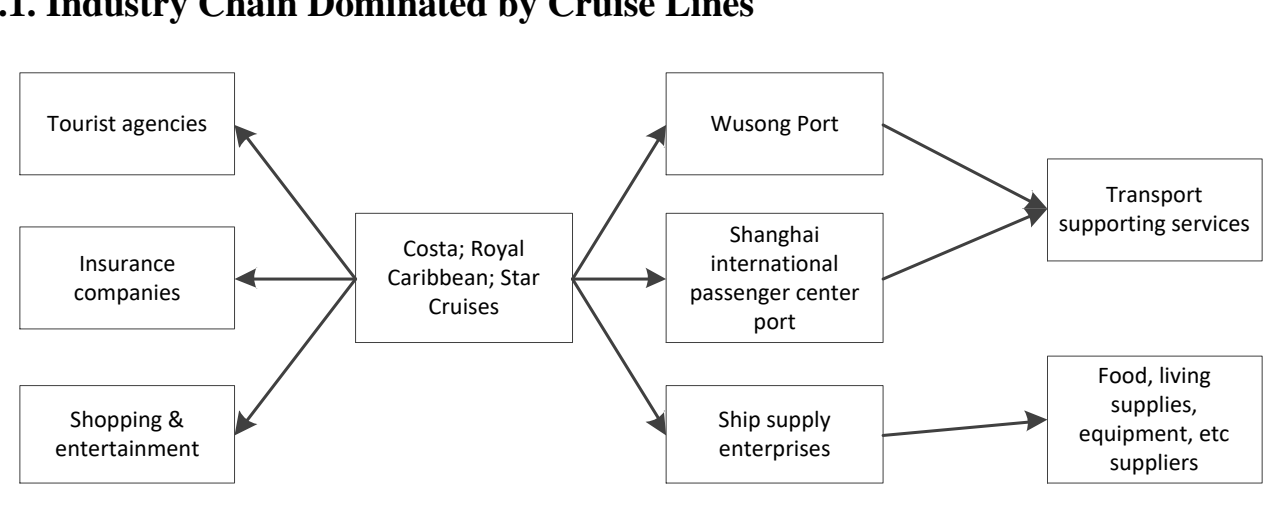

Figure 3. The Structure Chart of Industry Chain Dominated by Cruise Lines

The structure chart above shows that the structure of Shanghai cruise industry chain is undeniably episodic. Foreign cruise lnes dominate the industry chain and the benefits for local enterprises can t be assured equally.

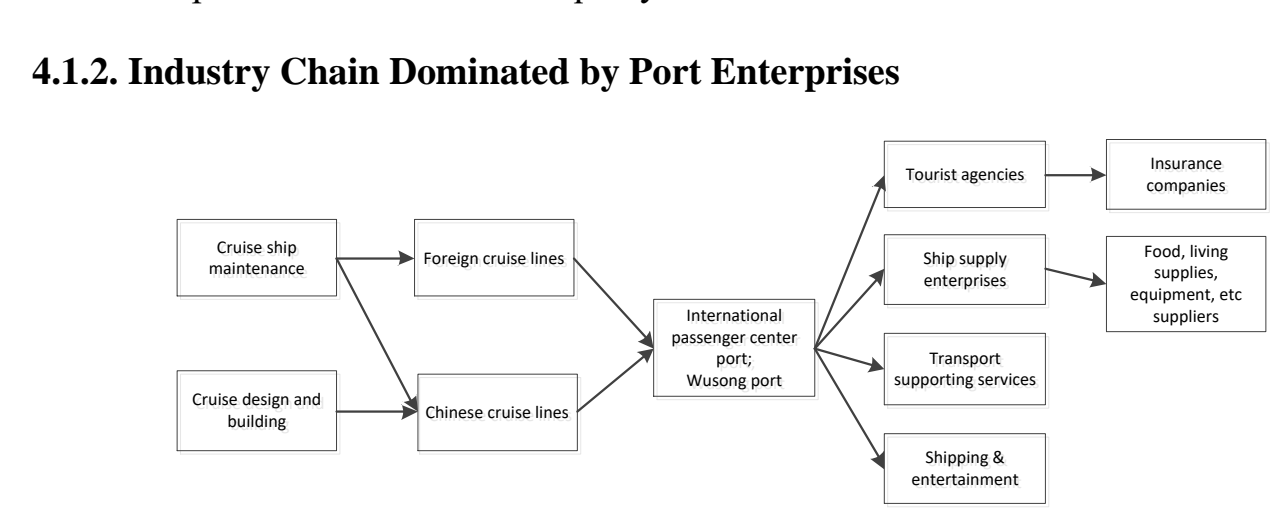

\section{Figure 4. The Structure Chart of Industry Chain Dominated by Port Enterprises}

Only when the homeport dominates the industry chain can Shanghai cruise industry chain be more tight and perfect and local enterprises can establish strategic cooperative relationship. 


\subsection{The Object of the Cruise Industry Chain benefits Distribution}

The object of benefits distribution is both the carrier of benefits and the taker of some risks. The object of the cruise industry chain benefits distribution includes these downstream industries like ship supply, ashore tourism, commercial trade, recreation, leisure, insurance, transportation and other related service industries.

\section{The Construction and Measurement of Cruise Industry Chain benefits Distribution Model}

Shanghai cruise industry chain is a huge and complex system, and the most important sections are cruise lines and cruise ports. Game theory is used in this paper to maximize Shanghai cruise industry chain benefits. We analyze the ratio of the benefits distribution by assuming and calculating Stackelberg, Shapley and Nash Model.

\subsection{Game Analysis of Shanghai Cruise Industry Chain}

Assuming that Shanghai cruise industry chain is made up with enterp fise $A, B$ and enterprise $\mathrm{C}$, and $\mathrm{A}$ represents for cruise line, $\mathrm{B}$ represents for pott company, C represents for supporting service enterprise which in a minimum following position while A and B are dominant enterprises. At the beginning of the industiy chain, the core enterprise cruise line and non-core enterprises — port company and supporting service enterprise like the master and slaves, so the Stacklberg model is fit for them. The first is the optimal decision of the cruise lines and then the optimal decision of port companies and supporting service enterprises. The cruise line is in the absolute dominating position, and port company can dominate local supporting service enterprise

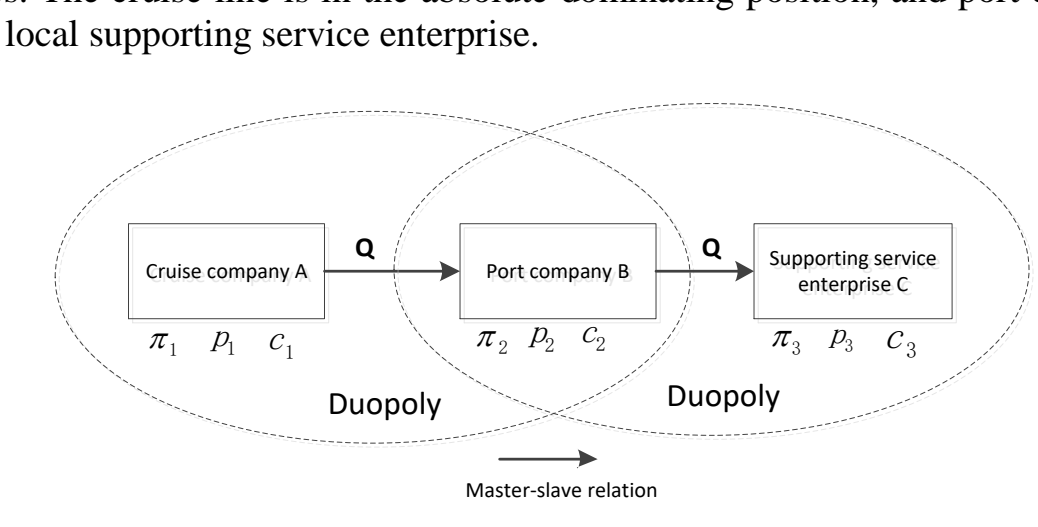

Figure 5. Indystry Chain Model Dominated by Cruise Company

With the improvement of Shanghai cruise industry chain, port company becomes the leader and the cooperation in the chain will be improved. In this situation, the game relationship in Shanghai cruise industry chain is cooperative game relationship and the Shapley model can be used to figure up the specific proportion of benefits distribution.

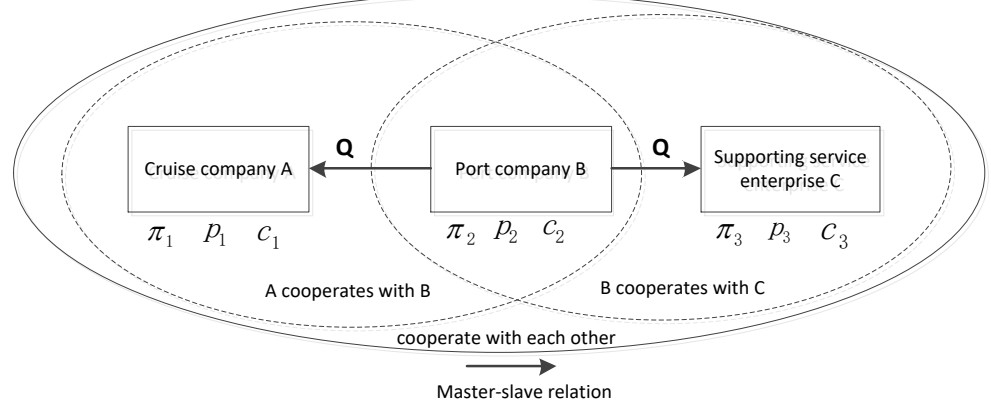

Figure 6. Industry Chain Model Dominated by Port Company 
At the beginning of Shanghai cruise industry chain, cruise line A is the leader which determines the distribution and can make first decision. The later then know the leader's decision and make their decisions. Cruise line A decides cruise ships voyage and quantity. Though port company $\mathrm{B}$ is dominated, it has more advantages than $\mathrm{C}$ because of the government's supports.

\subsection{Model Assumption}

(1) Enterprises A, B, C in line with the rational man hypothesis. They share information with each other and aim to maximum benefits. The principleof leader acting first is followed;

(2) Assumingthat cruise company's sales price isp ${ }_{1}$, port company's unit service fee is $\mathrm{p}_{2}$, and supporting service enterprise's unit service fee is $\mathrm{p}_{3}$;

(3) Assuming that unit cost of cruise company, port company and supporting service enterprise are respectively $\mathrm{c}_{1}, \mathrm{c}_{2}$, and $\mathrm{c}_{3}$;

(4) Assuming that unit profit of cruise company, port company and supporting service enterprise are respectively $\pi_{1}, \pi_{2}$, and $\pi_{3}$, the total unit profit of Shanghai cruise industry chain is $\pi$;

(5) Assuming that cruise market demand function is a linear function,

(6) $\mathrm{Q}=\mathrm{a}-\mathrm{b}\left(\mathrm{p}_{1}+\mathrm{p}_{2}+\mathrm{p}_{3}\right)$

(7) In the function, $a>0, b>0$, and both $a, b$ are constant. $Q$ represents the person-time of cruise, a represents the maximum person-time, $b$ represents price elasticity of demand;

(8) After Shanghai cruise industry chain is improved, every enterprise is able to be cooperated with others and the following four kinds of cooperation will be formed. The first kind is (A, B, C) which means every enterprise doesn't cooperate with others. The second kind is $((A, B), C)$, this means cruise company and port company are cooperated, and suppoting service enterprise is alone. The third kind is (A, (B, $\mathrm{C})$ ), cruise company is alone while port company cooperates with supporting service enterprise. The last kind is when three enterprises participate in the union, this is $((\mathrm{A}$, $\mathrm{B}, \mathrm{C})$ ).

\subsection{Analyzing the Benefits Distribution of Cruise Industry Chains Dominated by} Different Enterprises

Table 4. Shanghai Cruise Industry Chain Game Analysis

\begin{tabular}{|c|c|c|c|c|c|c|}
\hline $\begin{array}{c}\text { Industry } \\
\text { chain model }\end{array}$ & $\begin{array}{l}\text { Game } \\
\text { method }\end{array}$ & $\begin{array}{c}\text { Cruise } \\
\text { company } \\
\text { distibution }\end{array}$ & $\begin{array}{c}\text { Port } \\
\text { company } \\
\text { distibution }\end{array}$ & $\begin{array}{l}\text { supporting } \\
\text { service } \\
\text { enterprise } \\
\text { distribution } \\
\end{array}$ & $\begin{array}{c}\text { Industry } \\
\text { chain } \\
\text { total } \\
\text { profits }\end{array}$ & $\begin{array}{l}\text { Propotion } \\
\text { of benefits } \\
\text { distribution }\end{array}$ \\
\hline Cruise & Stackelberg & $\Delta$ & $\Delta$ & $\Delta$ & $7 \Delta$ & \multirow{2}{*}{$4: 2: 1$} \\
\hline $\begin{array}{l}\text { company } \\
\text { dominating }\end{array}$ & model & $\overline{16}$ & $\overline{32}$ & $\overline{64}$ & $\overline{64}$ & \\
\hline \multirow{4}{*}{$\begin{array}{l}\text { Port } \\
\text { company } \\
\text { dominating } \\
\text { Enterprises } \\
\text { in equal } \\
\text { status }\end{array}$} & \multirow{2}{*}{$\begin{array}{c}\text { Shapley } \\
\text { cooperative } \\
\text { game model }\end{array}$} & $13 \Delta$ & $47 \Delta$ & $23 \Delta$ & $\Delta$ & \multirow{2}{*}{$\frac{13}{48}: \frac{47}{96}: \frac{23}{96}$} \\
\hline & & $\overline{192}$ & $\overline{384}$ & $\overline{384}$ & $\overline{4}$ & \\
\hline & Nash & $\Delta$ & $\Delta$ & $\Delta$ & $\Delta$ & \multirow{2}{*}{$1: 1: 1$} \\
\hline & $\begin{array}{l}\text { equilibrium } \\
\text { model }\end{array}$ & $\overline{12}$ & $\overline{12}$ & $\overline{12}$ & $\overline{4}$ & \\
\hline
\end{tabular}

$\Delta$ is only concerned with maximum person-time, price elastic coefficient and unit person-time total cost. Maximum person-time and price elastic coefficientare constants 
and don't change with the enterprise's decision-making. Cruise enterprise cost mainly includes fixed cost, financial expense interest cost and variable costwhich changed with the person-time. Fixed cost mainly means depreciation expense of fixed assets. When the person-time is the same, $\Delta$ of these three models will not change leading to benefits distribution in different situation can be compared. The final analysis conclusions are as follows:

(1) The distribution 4:2:1 means over $50 \%$ of profits are earned by cruise company and Shanghai cruise industry must experience it. It may like China building up the stage but foreigners singing on the stage, but only in this way can attract more cruise ships to call at Shanghai or to see Shanghai port as homeport and therefore supporting service enterprises in the downstream cruise industry chain can be developed.

(2) Only when port enterprise is the leading enterprise can Shanghai cruise industry economic benefits be maximal and every enterprise win.

(3) Gaming under idealized Nash equilibrium is every enterprise's expectation. Benefits distribution of everyone in the industry chain will be equal if there are no outside intervention and resources superiority. Only in this idealized mode/can get the maximum industry chain benefits.

(4) Designed profit of Chinese port enterprises port charge is only $3 \%$ while foreign homeports are $15 \%$. With the improvement of cruise industry chain, when $\Delta$ is fixed, port company distribution will change from $\frac{\Delta}{32}$ to $\frac{47 \Delta}{384}$ cruise company distribution will change from $\frac{\Delta}{16}$ to $\frac{13 \Delta}{192}$. Furthermore, supporting service enterprise distribution will significantly increase from $\frac{\Delta}{64}$ to $\frac{234}{384}$, proving that homeport economic has significant distribution to downstream industry.

The 12th five-year plan predicts cfulse touris to be one million. In this situation, we can calculate unit cost is 4,928 Yan. Figure 7 shows benefits distributions of different enterprises in different models.

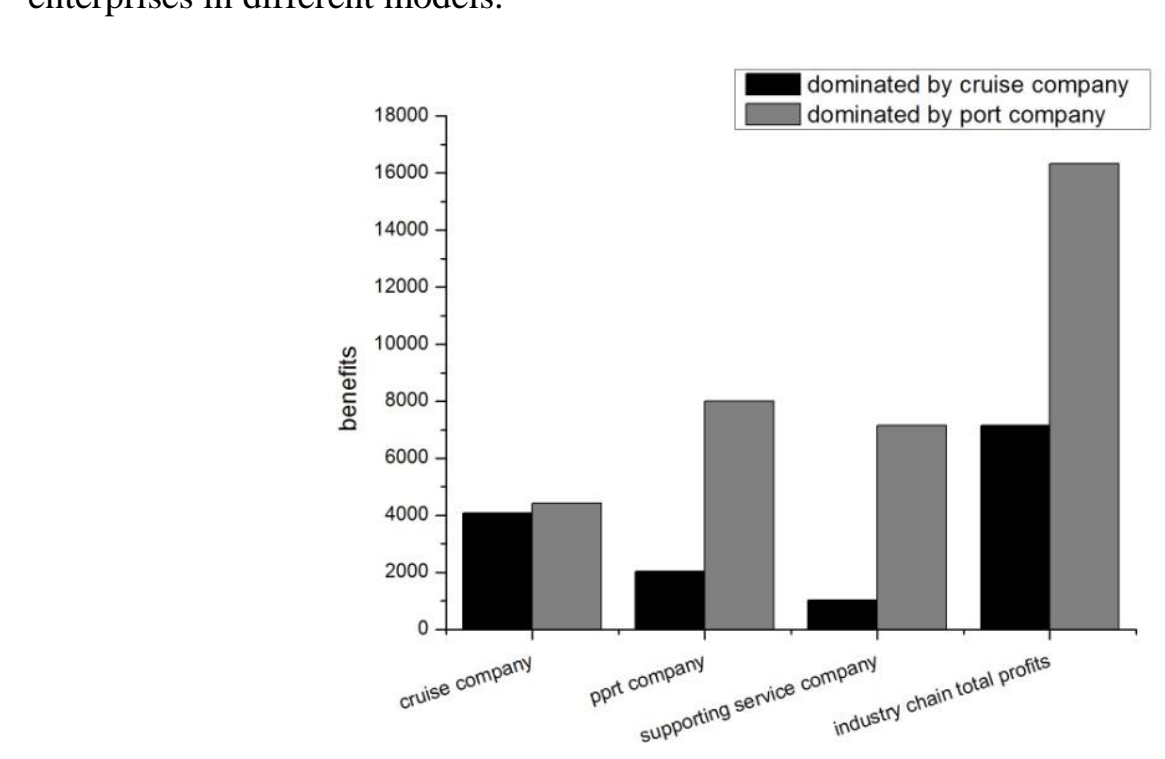

Figure 7. Shanghai Cruise Industry Chain benefits Distribution

When homeport leading the cruise industry chain, port company can increase about 60 million Yuan per million person-time and total profit of Shanghai cruise industry chain will increase 90 million Yuan to 160 million per million person-time. 


\section{Conclusion}

This paper has outlined the benefits distribution of Shanghai cruise industry chain now is $4: 2: 1$ which means foreign cruise companies earn the most of cruise industry benefits. In order to maximize cruise economic benefits, cruise homeport ought to gradually replace the cruise company's dominantposition and the distribution should be $\frac{13}{48}: \frac{47}{96}: \frac{23}{96}$. The feasibility is validated and this kind of benefits distribution can make the cruise industry chain economic benefit be maximal.

At the end of this paper, the following suggestions are given:

(1) Urging to own proprietary cruise

Firstly, researching foreign luxury cruise ship deeply, investigating potential tourists in China and the way of tourists entertainment, searching for the breakthrough in shipbuilding talents and technology. Secondly, guiding and supporting powerful enterprises to establish local registered cruise lines. Als $\varnothing$, cooperating with Korea in building cruise ships or establishing joint ventures can be considered. Thirdly, related departments shouldmake some polices about financing and tax deduction and exemption, and should encourâge diversifited investments. Fourthly, introducing or leasing foreign cruise as a supplement. Forelgn cruise liens' monopoly should be destroyed and avoiding the phenomenon of cruise economic leakage.

(2) Creating chance for downstream industries to getinvolved

China should pay attention to regiona supporting function, exploit commerce, entertainment, food \& beverage and other high additional value projects.More comprehensive reception consumption such as gruise supply, M/R, waste disposal should be set up. Besides, we oughto strive to cevelop derivative industry to offer diversified and personalized service like establishing a cruise city and so on. Government should encourage related enterprises to develop tourism project and enrich the connotation of crulise tourism products according to different markets.

(3) Speeding up the upstream design and cultivate the cruise market and talents

Establishing an organization consists of some departments to coordinate every link of cruise industry chain. Making preferential policies about voyage subsidies, cruise goods export tax rebates Clocal operation and so on. Gradually open gaming entertainment on the ship. Cutting down the time of customs declaration and inspection and simplify the embarkation and disembarkation procedures. Trying to develop some diversified, private customized and shorter cruise tourism products which has low expense and are close to the shore and also have specific topic. Considering the lack of cruise talents, some related advanced courses are offered in universities to cultivate high-level managing talents with international view and practical ability. In addition, learning from international cruise economically developed countries and introducing foreign high-level managing talents.

These are what authors researched on Shanghai cruise industry chain distribution af benefits. we wish this paper can offer some references to the development of ruise industry.

\section{References}

[1] S. Véronneau, J. Roy, "Global service supply chains: An empirical study of current practices and challenges of a cruise line corporation[J]", Tourism Management, (2008), no. 5, pp. 1-12.

[2] M. G.Abbas, "Cruise ships and small island economies: Some evidence from the Caribbean region.", Ph.D., Kent State University, (1989): 195.

[3] L. Dwyer, P. Forsyth, "Economic significance of cruise tourism[J]", Annals of Tourism Research, (1998), vol. 4, no. 25, pp. 393-415. 
[4] H. Iwata, K. Matsuda, "Haptic walkthrough simulator: its design and application to studies on cognitive map[R]", The 2nd International Conference on Artificial Reality and Tele-existence, ICAT. (2003), pp. 185-192.

[5] Development Research Center of the State Council.Cruise economic - an important economic growth pole of port city[R]. (2003), pp. 19-21.

[6] Y. Sijia, S. Shan, "An Overall Understanding on the Passenger Liner Economy[J]. SHANGHAI URBAN PLANNING REVIEW”, (2005), pp. 28-32.

[7] M. Youhong, J. Wenzheng, J. Yongbo, "Measurers of Investment Risk Control for Cruise Terminal[J]. RESEARCH ON WATERBORNE TRANSPORTATION", (2008), no. 2, pp. 18-20.

[8] Y. Min, C. Juan, "The problem and strategy of Chinese cruise tourism market development[J]", MODERN BUSINESS TRADE INDUSTRY, (2009), no. 4, pp. 96-97.

[9] X. Lian, "Chinese cruise industry chain needs to grow[J]", MARITIME CHINA, (2011), vol. 3, no. 69.

[10] S. Ling, Y. Chenguang, Z. Yuyin, "The Analysis of Surrounding Economic Triggered by Cruise - Analysis Based on the Study of the United States[J]; Traffic \& Transportation, (2013), (z2), pp. 137-140.

[11] S. Xiaodong, F. Xuegang, "Cruise Tourism Industry in China: Present Situation of Studies and Prospect [J]", Tourism Tribune, (2012), no. 9, pp. 101-112.

[12] T. Yu, "Research on Third-party Logistics Subcontract Design Based on Stackelberg Ganie Being Nash Equilibrium[J]", JOURNAL OF INDUSTRIAL ENGINEERING AND ENGINEERING MANAGEMENT, (2005), vol. 19, no. 4, pp. 100-103.

[13] B. Jianhua, F. Shijian, "Coal,Electrical and Metallurgical Indưstry Stratègic Allance and the Analysis of Profit Allocation by Game Theory[J]", OPERATIONS RESEARCH AND MANAGEMENT SCIENCE, (2004), no.5, pp. 24-29.

[14] Z. Guilei, L. Zhixue, "A Stackelberg Game of Profit Division in Supply Chains with Dominant Firms [J]”, SYSTEMS ENGINEERING, (2006), vol. 24, no. 11, pp. 19-23].

[15] D. Jianhua, X. Hengxin, "The Strategy of Profit Allocation among Partners in Dynamic Alliance Based on the Shapley Value[J]. CHINESE JOURNAL OF MANAGEMENTSSCIENCE, (2004), vol. 12, no. 4, pp. 33-36.
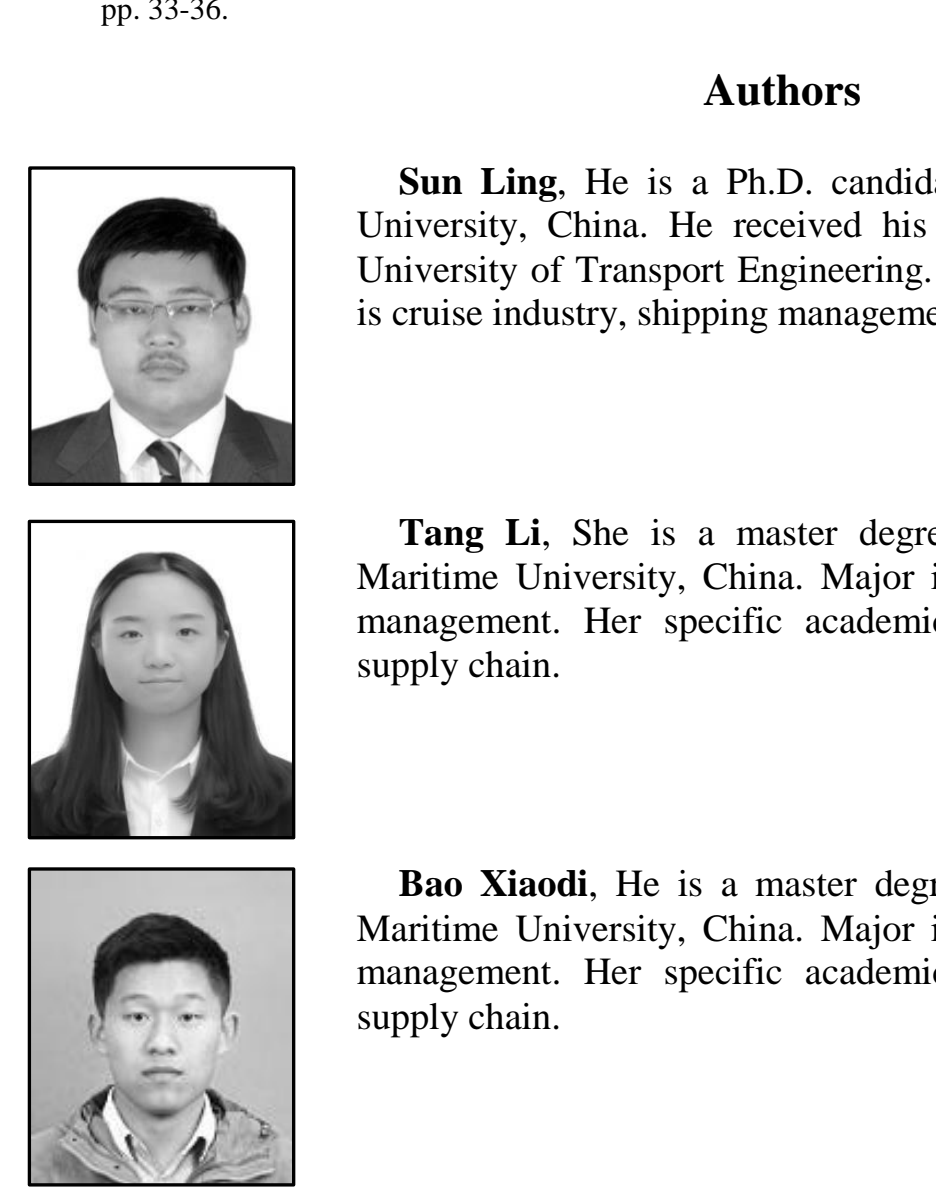

Sun Ling, He is a $\mathrm{Ph}$. D. candidate in the Shanghai Maritime University, China. He received his Master's degree in the same University of Transport Engineering. Ling's specific academic field is cruise industry, shipping management and green logistics.

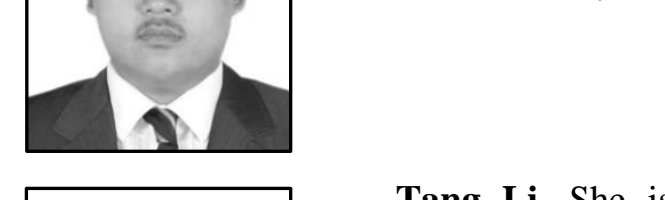

Tang Li, She is a master degree candidate in the Shanghai Maritime University, China. Major in transportation planning and management. Her specific academic field is cruise and service supply chain.

Bao Xiaodi, He is a master degree candidate in the Shanghai Maritime University, China. Major in transportation planning and management. Her specific academic field is cruise and service supply chain. 


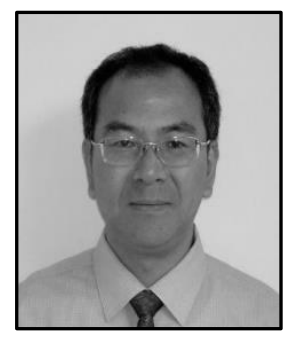

Liu Wei, He is a full professor in transport \& communication college, Shanghai Maritime University, China. His specific academic field is transportation and modernization of logistic management. Prof. Liu is a member of Reviewing Expertise Group of National Natural Science Foundation of China (NSFC), IEEE International Conference committee.

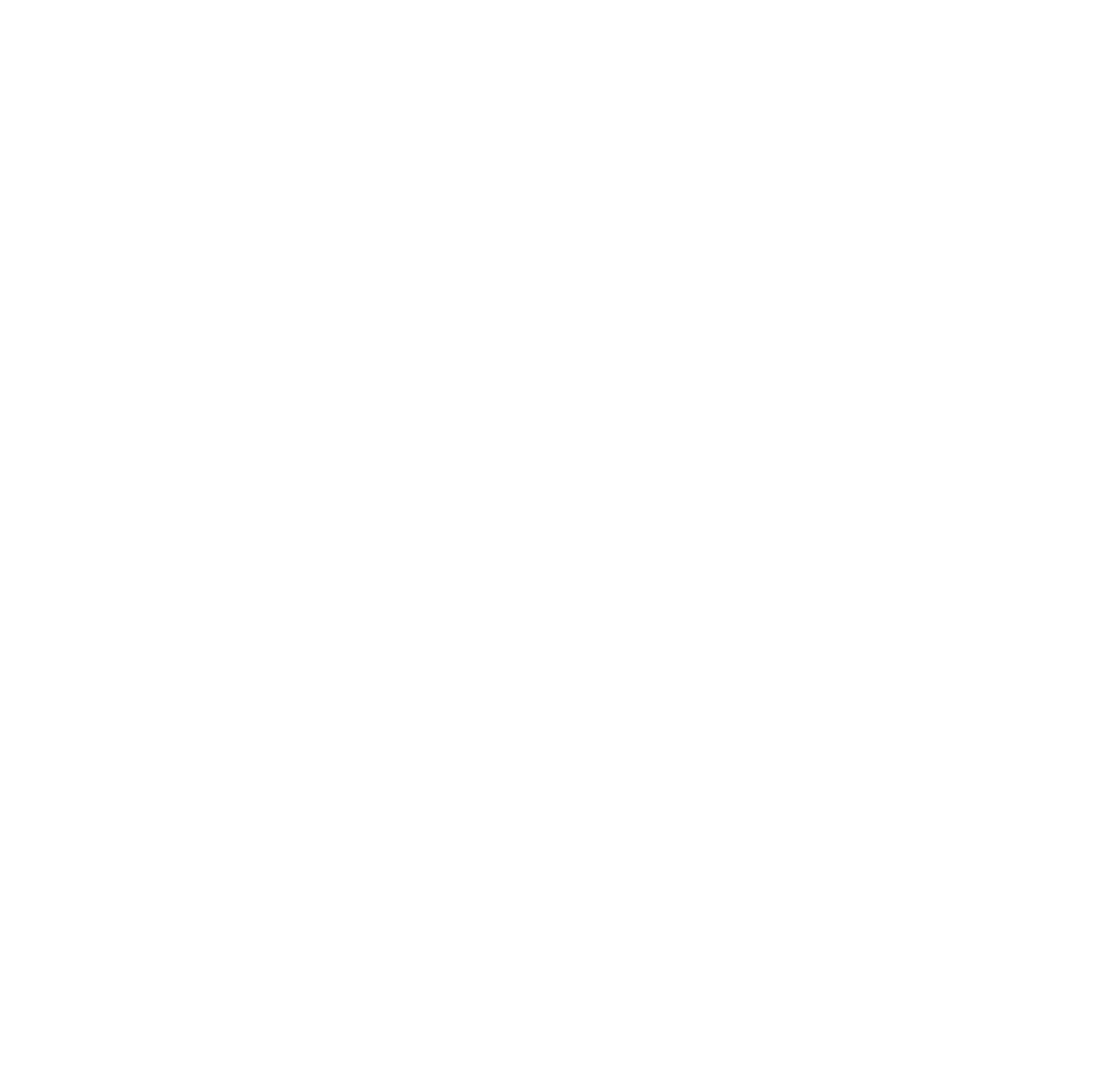

